UDC $372+004.5$

\author{
Antonina V. Hryvko \\ PhD of Pedagogical Sciences, \\ Senior Researcher at the Monitoring and Assessment of the Education Quality Department \\ Institute of Pedagogy of the National Academy of Educational Sciences of Ukraine, Kyiv, Ukraine \\ ORCID ID: 0000-0001-9460-4777 \\ av.hryvko@gmail.com
}

\title{
STRUCTURAL AND METHODOLOGICAL ASPECTS OF RESEARCH TYPOLOGIZATION ON THE USE OF ICT IN SECONDARY SCHOOL
}

\begin{abstract}
The article features a methodology for systematization of research on ICT use in secondary education. Making important decisions about improving school education, including through the introduction of certain information and communication technologies into the educational process, is based on the study of relevant experience and relevant research results. The large number of diversified scientific works that make up the theoretical, practical, and methodological basis of the ICT use in school education necessitates the generalization, ordering, and determination of their typological features.

The author singles out the following groups of studies related to the ICT use in school: generalizing theoretical-analytical (documentary), empirical and complex. Each of the groups is characterized by a variable set of typological features in terms of scale and independence of their conduct. They allow distinguishing their main types (10 types of research are considered in the article, for example, empirical/international large-scale/contextual studies or complex/local/separate studies, etc.). The author determined the structural and methodological criteria for the analysis of different research types (thematic, targeted, sampling, organizational, methodological, analytical, resultant) and carried out a selective analysis of the studies on the proposed typological features, structural and methodological criteria, the results of which were systematized in the matrix of methodological analysis of different research types on the ICT use in school education.

According to the results of the works review, topical thematic areas of the analyzed research were identified, typical methods of data collection and analysis were singled out and the format of results reporting was highlighted for each selected research group.

The approach to systematizing research on the use of ICT in secondary education institutions, presented in the proposed article, can be applied during the review of scientific achievements, the analysis of pedagogical research in the field of ICT, or to design individual research. Filling in the proposed analysis matrix will allow it to be further used as a database of relevant research papers, facilitate the search and selection of those that meet the objectives of a specific scientific search.
\end{abstract}

Keywords: ICT in education; research methodology; types of research; methodological analysis criteria.

\section{INTRODUCTION}

Problem statement. The use of ICT in the educational process is a modern educational trend, driven by information and technological development and the demands of society. Evaluation of the effectiveness and feasibility of ICT implementation in education is determined by the research findings, which can test (prove or refute) assumptions about identified or possible patterns or dependencies caused by the use of computer-oriented technologies and learning tools, and accumulate scientifically-based theoretical information needed to make important decisions about improving school education.

The methodology of using ICT in the learning process is based on research results that are quickly becoming obsolete due to the rapid development and diffusion of the technology itself. This, therefore, leads to a large number of such studies, which creates opportunities to 
reach plausible conclusions and improve the methodology for a comprehensive study of the ICT problem in education, not only by considering the results of numerous studies but also by the methods of conducting them. Therefore, each subsequent study relies on practicallyoriented knowledge derived from previous similar or tangential research. This means that in the process of designing your own research (concept development, strategy development, selection of methods, etc.) it is important to take into account both already known knowledge and previous conducting experience of such research. For this purpose, it is necessary to be guided in rather a big array of researches. This necessitates their typologization and systematization, which will serve as methodological guidelines for further research by both Ukrainian and foreign scientists in the field of ICT use in secondary school.

Analysis of recent studies and publications. The analysis of publications, the authors of which review research on the use of ICT in education, allowed us to generalize that scientists analyze and systematize such research mostly on a thematic basis (for example, the works of O. Voronkin [1], O. Kolgatin, L. Kolgatina [2]). Simultaneously, to summarize the experience and systematize the methodological aspects of research into the problems of using ICT in general secondary education, important publications are works, in which authors examine survey tools, methods of their application, and analysis of results. Such works primarily include research reports ([3] - [9]); generalized manuals that are the theoretical and practical basis for planning and conducting further research - for example, the work of J. Cresswell, U. Schwantner and Ch. Waters (2015), who described the methodology for reviewing large-scale international researches in the aspect of contextual data collection - in particular, the authors provided information on the different approaches to survey tools used in different types of educational monitoring studies (including, for example, contextual surveys on the level of technological provision of the educational process in schools) [9]; articles that reveal the results of individual studies ([11] - [14]). Valuable in terms of our study are the works of the scientists who study the methodology of conduction of comparative research (M. Krasovytskyi, N. Lavrychenko, O. Lokshyna, O. Ovcharuk, S. Sysoieva and others [15]). A large number of works, the totality of which forms the methodological basis for the ICT use in school education, necessitates the systematization of ways of obtaining and analyzing relevant practically-oriented scientific knowledge.

The purpose of the article. The purpose of the article is to systematize the review of research on ICT use in secondary education institutions based on their typologization and analysis of the methodology for their implementation. In other words, the purpose of the proposed article is to systematize methodological information: what are the problems of using ICT in school education which are relevant to today? What types of research are aimed at examining and solving these problems? What methods of data collection and analysis are used in relevant studies? What information can be obtained from the results of these studies? The analysis of these issues will help to create a basic matrix of research of different types, which will integrate knowledge about the process and study effectiveness and will serve for scientists as information and descriptive basis to study current issues of ICT use in school education.

\section{THEORETICAL BASIS OF THE RESEARCH}

The research review as a "detailed study of a subject, especially to discover (new) information or reach a (new) understanding" [16], in particular on the problems of using ICT in school education, was carried out in the main substantive methodological directions: knowledge functioning (addition, updating, new knowledge formation); structure and operational composition of methods of knowledge acquisition and updating. The first 
determined direction is the study of current research topics. The second is the methods of information collecting and analyzing.

The review and characterization of numerous studies on the use of ICT in school education, due to their multidimensionality and diversity, necessitated the generalization, ordering and separation of typological features of such studies. According to [17, p. 2], "a widely applied way of classifying educational research studies is to define the various types of research according to the kinds of information that they provide", for example, historical research, descriptive research, correlational research, ethnographic research, etc. However, because the studies discussed in the proposed article are related thematically, which may cause similarity of the information presented in them, the basis of their classification may, in our opinion, be a way of collecting data during the research process. Thus, all the studies that form the knowledge bank on the use of ICT in the educational process can be divided into 3 groups: generalizing non-empirical theoretical and analytical desk (or secondary) research (that can be done from a desk, for example, study and literature review on the topic, reading reports or using the Internet for searching information); empirical/primary - an empirical search for knowledge (using observations, surveys, experimental work) about the experience of using ICT in the educational process; complex (mixed-method research) (Fig. 1). We should note that such division is conditional since any research has a theoretical basis or hypotheses formulated on the basis of existing information.

The studies of each of these groups are characterized by a variable set of typological features distinguished on the basis of terminology analysis in the field of educational research (to clearly define the terms used in the article - research, study, survey, large-scale survey, local research, desk research, separate research, supplementary research, empirical study, mixed-method, review, overview, etc. - definitions presented in different vocabulary bases [17], [18] - [21] were analyzed). The distinguished typological features of the analyzed studies are the following: 1) the scale of the study-large-scale international research (large in scope of sample and in the wide area of conducting); large-scale national research; local (conducted at a regional or local level); 2) research independence - separate research (conducted separately and directly aimed at achieving the objectives of the study) and supplementary or contextual - part of multi-purpose educational study or monitoring and aimed at solving one of the several objectives of the study (usually collecting contextual additional information).

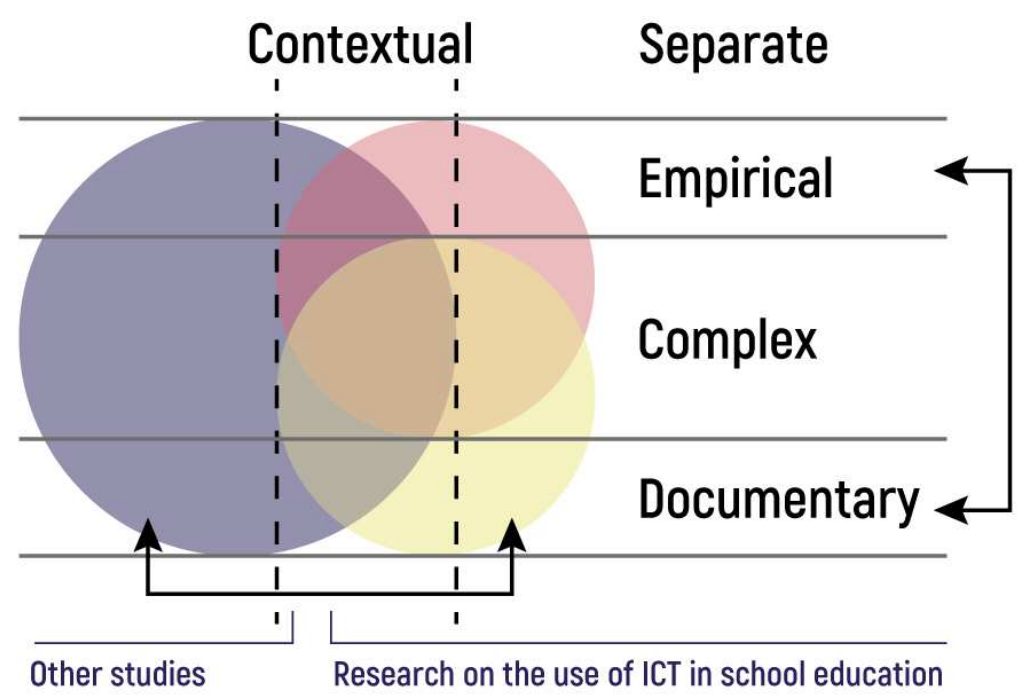

Fig.1. Types of research on the use of ICT in school education 


\section{RESEARCH METHOD}

The study presented in the article in a generalized form was carried out in 2 stages. The first stage was to look for research which focuses on the use of ICT in secondary school, employing databases of electronic repositories (Wiley Online Library, ScienceDirect (Elsevier), the Educational Resources Information Center (ERIC), SAGE Knowledge Platform, Google Scholar), and online libraries of organizations responsible for the research conduction (OECDiLibrary, Eurydice, A NSW Government website - Education). The search for required works was conducted using several keyword combinations (including "ICT in school", "ICT for teaching and learning", "using ICT in education", "effect of ICT" etc.), as well as using the snowball method. From the set of reviewed works following the dimensions "generalizability", "trustworthiness", "importance" (A. Schoenfeld) [22] and proposed typological features, the most typical studies related to general issues of ICT use in secondary school were identified.

The second stage was to determine the structural and methodological criteria for analyzing the studies under consideration. Given the methodological features of research on the use of ICT in school education, the following criteria have been identified:

thematic - a range of issues that research is aimed at;

targeted - purpose of the study - ascertaining studies (gathering statistical information on the state of ICT dissemination in education, access to ICT in schools; gathering of analytical information on the progress of the ICT use in school education - change dynamics, comparison, comparison of experiences, etc.). Such studies, by [17, p. 5] can be "summative" (by evaluating the worth of the final product, especially in comparison to some other competing product) and practically-oriented, related to the need to make important decisions, action plans, strategies, e.g., to update the content of the education required for the use of ICT and study tools, or limitation or expansion of access to certain devices for the participants of the educational process due to the analysis of the benefits and risks associated with the use of ICT, and so on. Such studies are called "formative" (which consist in collecting evaluative information about the product while it is being developed to use such information to modify and improve the development process) [17, p. 4]);

sampling - for theoretical and analytical studies - criteria for selecting sources (scientific papers, reports, research, etc.) for further analysis; for empirical research - the category of respondents who participate in the research (students, parents, teachers, principals) and sampling methods;

organizational - data collection procedure: for documentary studies - the format of the analyzed data (conference materials, scientific journals, research reports, research organizations statistics, etc.), for empirical studies - data collection format (paper-and-pencil mode, computer-assisted mode);

methodological - collection methods (literature analysis on the topic, observation, surveys, interviews, focus groups, experiment) and data type (numeric, verbal, verbalnumerical);

analytical - methods of processing the results of the study (descriptive, mathematical, statistical, etc.);

resultant - the format of results presentation (scientific article, review, report, manual).

\section{RESEARCH RESULTS}

An analysis of the works which highlight the research results on the use of ICT in secondary education institutions has made it possible to distinguish the following main types of them (by the proposed typological features): 


\section{empirical:}

1) large-scale international, separate (this type of empirical research includes a largescale, international benchmarking survey "Survey of Schools: ICT in Education. Benchmark progress in ICT in schools", corresponding to the Digital Education Action Plan data and records regarding digitization in education and digital technologies in learning [1]; conducted in 31 countries (the EU28, Norway, Iceland and Turkey) by the European Commission in a partnership between Ipsos, an independent market research company, and Deloitte, the world's largest consultancy firm;

2) large-scale international, contextual (such studies are conducted in the context of large-scale international studies to collect contextual information, which has mostly additional explanatory character regarding the purpose of the main research: as noted in [10], the work, the context framework provides the theoretical underpinning of the context variables and factors implemented in the survey, as well as how they relate to achievement. This process is used in PISA, PIRLS and TIMSS, World Education Indicators' Survey of Primary Schools (WEI-SPS) and the International Adult Assessment Program Competencies (PIAAC) [10, p. 24];

3) large-scale national, separate (an example is a study entitled "The role of information and communication technologies in teaching and learning processes in primary and secondary schools" [12], conducted in Spain, covering 35 schools (1 222 teachers) from 5 country's regions, and aimed at studying how ICT is contributing to the development of teaching and learning processes; and what, if any, are the differences between teachers at different school levels [12, p. 213];

4) local, separate (studies conducted locally: for example, the study "Teachers' innovative use of computer technologies in the classroom" [13], aiming to explore secondary school teachers' innovative use of computer technologies in the classroom; conducted in 14 Ghana schools, comprising 5 urban schools, 5 semi-urban schools and 4 rural schools);

documentary (theoretical and analytical):

5) international, separate (for the most part, they are the theoretical basis for empirical research or contain elements of empirical research which help to find or refine data (in this case they are complex). However, some are aimed at the comparative analysis of the scientists' achievements on the subject under study. Such literature reviews can be attributed to the separate international studies only if their practical importance is actually at the global international level, which determines the scale of the analyzed sources and the comparative statement of the results. Such studies include the "Meta-review of ICT in Education" [7]. This review was conducted in response to the terms of reference for GeSCI (The Global e-Schools and Communities Initiative (GESCI) is an international non-profit organization founded on the recommendation of the United Nations Task Force on Information Communication Technology). The purpose of this research was to provide a multi-disciplinary, multi-method lens for understanding the complexity and exponential growth of ICT around the world [7, p. 1]);

6) national, separate (project "Effective use of ICT in schools. Analysis of international research" [8]) aimed at studying the conditions of the positive impact of ICT on schooling and promoting the achievement of educational goals. Although this project was an international survey of research and research reports on the use of ICT in school education, we refer it to national research: it was implemented in Sweden by T. Skarin, an analyst and senior advocate at Metamatrix Research and Consultancy, tasked by the Swedish National Agency for School Improvement to synthesize the findings of the studies analyzed and to provide recommendations for improving the effectiveness of technology use in schools in Sweden [8, p. 5]); 
7) local, separate (an example of a locally relevant analytics benchmarking study is "An Overview of e-Learning in China" [14], which is partially supported by the 12th FiveYear Plan of National Science Education: The Key Research Ministry of Education Topics (DIA140316). The purpose of the research was to study and analyze the development, opportunities and challenges of e-Learning in China to identify gaps and seek opportunities to improve the quality of ICT use in school education);

complex:

8) large-scale international, separate (an example is "2nd Survey of Schools: ICT in Education. Model for a highly equipped and connected classroom" [4] aimed at developing a conceptual model for a "highly equipped and connected classroom" (HECC), defining three scenarios of a HECC and estimating the costs to equip and connect an average EU classroom with advanced components of the HECC mode. The analyzed study involved the study of a large number of sources, selected according to each stage of its goal (characterization of HECC model measurements, definition and description of components of each measurement; development of HECC model implementation scenarios; calculation of costs required to implement the developed model in the average EU classroom) and conducting surveys, consultations, interviews with experts, expert groups and stakeholders);

9) large-scale national, separate (we refer to this type of research "Review into the non-educational use of mobile devices in NSW schools" [9], conducted by a team of government-commissioned researchers from the New South Wales (NSW) of Australia due to the need to develop a mobile technology policy in primary and secondary education. The purpose of the review was to identify the benefits and risks of using mobile digital devices in the different types of the NSW secondary education institutions to develop a policy that governs students' use of digital devices and online services in all NSW public schools. The study provided an international literature review on the use and impact of mobile digital devices in school, consultations, interviews (14 in-depth interviews were conducted with principals), focus groups (35 focus groups were conducted with students, parents and teachers) and surveys (13761 survey responses were collected). Considering the territorial distribution and sample scope, we refer this research to national large-scale);

10) local, separate (an example of a complex separate (independent) study conducted at the local level is dissertation research. Such work is the dissertation "Designing the Information Space of a Comprehensive Educational Institution" [29]. The purpose of this study was to develop a model of information space of a secondary education institution and ways of its formation based on the integration of modern ICT. The study is complex because it was conducted in several stages, which involved the application of theoretical and empirical methods of research. The local level of the study is determined by two factors: 1) sample size and territorial distribution (the pilot study involved 57 school principals in Kyiv (Ukraine)); 2) goal orientation and significance of the results (relevant for the research environment Ukrainian secondary education institutions).

The results of a sample analysis of different types of studies according to the proposed typological features and structural and methodological criteria are systematically summarized in the "Matrix of methodological analysis of different types of research on the use of ICT in school education" (Appendix A).

\section{CONCLUSIONS AND PROSPECTS OF FURTHER RESEARCH}

The analysis of the search results in electronic databases repositories related to the use of ICT in school has made it possible to make generalized conclusions about the relevant areas of such research: 1) research of different groups of respondents' attitude to the use of ICT in school (emotional and evaluation aspect); 2) identifying the impact (or evaluation of 
effectiveness) of using ICT on student learning outcomes (productive aspect); 3) evaluation of the status, progress and potential of ICT use in schools (comparative aspect); 4) assessing the readiness to use digital technologies and ICT competences of different respondents groups (competence aspect); 5) modelling of educational ICT environment (environmental aspect); 6) studying the specifics of a particular technology use (software, electronic resource, etc.) in the learning process (methodological aspect). When talking about specific studies (including those we have analyzed), it should be noted that their topics can relate to problems of both one and several directions. Therefore, as a basis for their overall typology, it is advisable to adopt a method of data collection in the research process, which allows distinguishing three groups among them: empirical, documentary and complex studies, characterized by certain typological features - scale and independence.

Methods of data collection in empirical research on the use of ICT in school education, as a rule, are observation, focus groups, consultations, peer-review, an experiment which is conducted in the case of studying the methodology aspect of technology use and involves the presence of experimental and control groups. Most commonly, empirical studies use the questionnaire method. Questionnaires are usually made up of two parts - collecting general demographic information (gender, age, etc.) and the main part according to the purpose of the survey. The items of questionnaires are divided into descriptive (e.g., focused on describing school infrastructure in the context of ICT use), correlational (aimed at finding dependencies, such as between ICT use and cognitive motivation), casual (aimed at, for example, identifying factors that determine the effectiveness of using ICT at school or comparing the learning outcomes of students who used technology in lessons and those who did not). According to the types of data collected during the survey, the questions of the questionnaire are divided into those that imply a numerical answer (numerical data representing statistical information), a verbal answer (qualitative data - mostly free answers to direct questions) and a verbalnumerical (as a the result of the survey, researchers receive numerical indicators of qualitative characteristics, for example, questions related to the evaluation of respondents by certain statements, or questions about the frequency or duration of certain technologies use). According to the form of items, questions are divided into dichotomous (mostly yes/no), open-ended questions; multiple-choice questions (suggest multiple choice); nominal variables (Likert-scale: three, four, five and ten-point scales; Osgood questionnaire - method of semantic differential); rankings. Most often, questionnaires for ICT use at school consist of multiple-choice questions and Likert-scale questions to quantify the qualitative data and make it fit for statistical analysis. To ensure the validity of the toolkit, the questionnaire is usually first submitted for evaluation by experts in the field of the problem under study. To ensure the reliability of research results, cross-surveys are often conducted, not only to examine the research question from the perspective of different respondents' categories (who answer the same questions) but also to check the accuracy of the information they provide. The numerical data collected from the survey are added to spreadsheets and analyzed using statistical methods: descriptive statistics methods (main indicators - mean, median, mode, standard deviation or variance) - for analyzing the demographic info (sample description), frequency of ICT use; determination of the Cronbach alpha's value - to determine the reliability of the questionnaire; Univariate ANOVAs - to determine the locus of the statistically significant multivariate effect (comparison of different sample groups averages); MANOVAs t-test - for comparing means of two groups of participants in the study (for example, the mean differences in the use of ICT by gender, school type, teaching methods or computer experience); Multiple Regression Analysis - to evaluate the relationship between one dependent variable and several independent variables (for example, determining the degree of dependence of digital competence on a number of ICT-based activities); Cohen's d effect size - to indicate the standardized difference between two means (for example, 
comparing survey results conducted at different times); Cluster analysis method - for example, to identify groups of students, teachers, and schools that resemble each other; etc. Analysis of transformed data is carried out with the help of special software - for example, SAS software, SPSS software, STATISTICA.

As far as desktop research is concerned, data gathering is nowadays largely through the use of electronic repositories and online resources, due to a large amount of work involved in examining the use of ICT in school education and the ability to automatically sort materials by filters. Consideration and selection of work for review is usually determined by the purpose of the study, the elements analyzed - by its tasks. The type of review determines the format of results presentation - review, published observation, discussions, lessons learnt.

Comprehensive research combines elements of empirical and theoretical research. Such a combination can be different: in one case, desk research is the basis of the empirical part of the study, and in the other, the empirical elements are used to refine the theoretical data (searches).

The format of results reporting depends on the scale of the study - in a local study, results are usually reported in a research article; in the case of a large-scale study, the results are presented in the form of a report (the main report covers the results and conclusions following the purpose and objectives of the study, may consist of several volumes in the case of broad topics; the technical report details the procedures for preparing for the study, the method of collecting data and analyzing the results, as well as feedback). Recommendations and procedural issues on the use of ICT in secondary school, based on the results of research, can be summarized in the form of a manual.

The proposed systematic review of research on the use of ICT in secondary education institutions can be used as a blueprint for analysis of pedagogical ICT research or as a basis for designing individual research. Further addition and extension of the proposed matrix of analysis (Appendix A) will allow researchers to navigate the array of studies, to select those that meet the objectives of a specific scientific search. The integration of knowledge in the developed matrix will help scientists to create an information and descriptive base for comparative research, which will greatly facilitate and simplify the procedure of information selection; to monitor world trends and national features of studying the use of ICT in secondary school; to regulate the methodology of conducting relevant research according to their type; to synchronize the methodological guidelines of domestic scientific research with foreign ones in accordance with current challenges in the international dimension; to develop a strategy of practice-oriented research taking into account the analyzed experience or to use the proposed criteria for the implementation of descriptive research.

The study of the methodological features of research on the use of ICT in school education requires further scientific research, which can focus on information on a set of studies according to a specific criterion (including thematic and targeted) and on the systematization of narrow-based research presented in relevant scientific journals.

\section{REFERENCES (TRANSLATED AND TRANSLITERATED)}

[1] O. S. Voronkin, "Information and communication technologies in higher education as an object of psychological and pedagogical research (second half of XX - the beginning of XXI century)", Informatsiini tekhnolohii v osviti, № 22, pp. 57-79, 2015 (in Ukrainian).

[2] O. Kolgatin, L. Kolgatina, "Information and communication technologies in education as a part of Ukraine pedagogical science in the field of theory of pedagogics in the 90th years of the 20th century", Information Technologies and Learning Tools, Vol 72, No 4, pp. 41-54, 2019 (in Ukrainian)

[3] 2nd Survey of Schools: ICT in Education. (2019). Objective 1: Benchmark progress in ICT in schools. Final report. Luxembourg: Publications Office of the European Union. 121 p. doi: 10.2759/23401. (in English). 
[4] 2nd Survey of Schools: ICT in Education. (2019). Objective 2: Model for a 'highly equipped and connected classroom'. Final report. Luxembourg: Publications Office of the European Union. 127 p. doi: 10.2759/831325. (in English).

[5] 2nd Survey of Schools: ICT in Education. (2019). Technical Report. Luxembourg: European Commission. 212 p. doi: 10.2759/035445. (in English).

[6] OECD. (2019). PISA 2018 Results (Volume I): What Students Know and Can Do, PISA, OECD Publishing, Paris, 354 p. doi: https://doi.org/10.1787/5f07c754-en. (in English).

[7] Meta-analysis of ICT: Research Report for GeSCI. (2009). [Online]. Available: https://files.eric.ed.gov/fulltext/ED506553.pdf. Accessed on: March 24, 2020. (In English).

[8] T. Skarin, "Effective use of ICT in schools. Analysis of international research", Report. Swedish National Agency for School Improvement, Metamatrix. Stockholm, Sweden, 2008. [Online]. Available: https://www.skolverket.se/download/18.6bfaca41169863e6a654128/1553957321459/pdf1971.pdf. Accessed on: March 24, 2020. (in English).

[9] Review into the non-educational use of mobile devices in NSW schools. (2019). Report. M. Carr-Gregg, S. McLean, A. Third, Eds. [Online]. Available: https://education.nsw.gov.au/about-us/strategies-andreports/our-reports-and-reviews/mobile-devices-in-schools/review-into-the-non-educational-use-ofmobile-devices-in-nsw-schools\#top-desktop. Accessed on: March 24, 2020. (in English).

[10] J. Cresswell, U. Schwantner, C. Waters, "A Review of International Large-Scale Assessments in Education: Assessing Component Skills and Collecting Contextual Data". PISA, The World Bank, Washington, D.C./OECD Publishing, Paris, 2015. http://dx.doi.org/10.1787/9789264248373-en. (In English).

[11] P. Wastiau, R. Blamire, C. Kearney, V. Quittre, E. Van de Gaer, Chr. Monseur, "The Use of ICT in Education: a survey of schools in Europe", European Journal of Education: Research, Development and Policy. Volume 48, Issue 1. Special Issue: ICT and Education: taking stock of progress and looking at the future, pp. 11-27, 2013. doi:https://doi.org/10.1111/ejed.12020. (in English).

[12] A. Sangrà, M. González-Sanmamed, "The role of information and communication technologies in improving teaching and learning processes in primary and secondary schools", ALT-J, Vol. 18 , No 3. 207-220, 2010. doi: 10.1080/09687769.2010.529108. (in English).

[13] Ch. Buabeng-Andoh, F. Totimeh, "Teachers' innovative use of computer technologies in classroom: A case of selected Ghanaian schools", IJEDICT, Vol. 8, Issue 3, pp. 22-34, 2012. (in English).

[14] Y. Wang, X. Liu, Zh. Zhang, "An overview of e-learning in China: History, challenges and opportunities", Research in Comparative \& International Education, Vol. 13(1), pp. 195-210, 2018. doi: 10.1177/1745499918763421. (in English).

[15] Comparative Pedagogy: methodological trends of Ukrainian scholars: chrestomathy. O. Lokshyna et al. K. : Pedagogchna dymka, 2015. (in Ukrainian).

[16] Meaning of research in English. Cambridge Dictionary. Definitions. [Online]. Available: https://dictionary.cambridge.org/dictionary/english/research. Accessed on: Apr.09, 2020. (in English).

[17] T. N. Postlethwaite, "Educational research: some basic concepts and terminology": Module 1 . UNESCO. IIEP, 50 p. 2005 [Online]. Available: https://unesdoc.unesco.org/ark:/48223/pf0000182459.locale=en. (in English).

[18] Collins: online-dictionary. [Online]. Available: https://www.collinsdictionary.com/. Accessed on: Apr.09, 2020. (in English).

[19] A Dictionary of Education. (2009). 1ed. . Ed. by S. Wallace. GB :Oxford University Press. doi: 10.1093/acref/9780199212064.001.0001. (in English).

[20] Cambridge Dictionary. [Online]. Available: https://dictionary.cambridge.org/. Accessed on: Apr.09, 2020. (in English).

[21] The Free Dictionary by Farlex. [Online]. Available: https://www.thefreedictionary.com/. Accessed on: Apr.09, 2020. (in English).

[22] A. H. Schoenfeld, "Research methods in (mathematics) education". In Handbook of International Research in Mathematics Education, L. English, Ed. Mahwah, NJ: Erlbaum, pp. 435-88, 2002. (in English).

[23] 2nd Survey of Schools: ICT in Education. (2019). Digital Single Market. [Online]. Available: https://ec.europa.eu/digital-single-market/en/news/2nd-survey-schools-ict-education. Accessed on: Apr.09, 2019. (in English).

[24] ICT familiarity questionnaire for PISA 2018. [Online]. Available: http://www.oecd.org/pisa/data/2018database/CY7_201710_QST_MS_ICQ_NoNotes_final.pdf. Accessed on: Apr.09, 2020. (in English).

[25] A. Schleicher, PISA 2018: Insights and Interpretations. OECD, 2019. (in English).

[26] OECD. (2011). PISA 2009 Results: Students on Line: Digital Technologies and Performance (Volume VI). 395 p. doi: http://dx.doi.org/10.1787/9789264112995-en. (in English). 
[27] OECD. (2015). Students, Computers and Learning: Making the Connection, PISA, OECD Publishing, Paris. doi: https://doi.org/10.1787/9789264239555-en. (in English).

[28] Student Use of Digital Devices and Online Services Policy. (2020). [Online]. Available: https://education.nsw.gov.au/content/dam/main-education/en/home/about-us/strategies-and-reports/ourreports-and-reviews/review-into-the-non-educational-use-of-mobile-devices-in-nsw-schools/Policy.pdf. Accessed on: Apr.09, 2020. (in English).

[29] H. O. Protsenko, "Designing information space of a comprehensive educational institution", Thesis, abstract. Institute of Information Technologies and Learning Tools of NAES of Ukraine. 2012. (in Ukrainian).

\title{
СТРУКТУРНО-МЕТОДОЛОГІЧНІ АСПЕКТИ ТИПОЛОГІЗАЦІЇ ДОСЛІДЖЕНЬ ЩОДО ВИКОРИСТАННЯ ІКТ В ШКІЛЬНІЙ ОСВІТІ
}

\author{
Гривко Антоніна Вікторівна \\ кандидат педагогічних наук, \\ старший науковий співробітник відділумоніторингу та оцінювання якості загальної середньої освіти \\ Інститут педагогіки НАПН України, м. Київ, Україна \\ ORCID ID 0000-0001-9460-4777 \\ av.hryvko@gmail.com
}

\begin{abstract}
Анотація. У статті в методологічному аспекті розглянуто питання систематизації досліджень щодо використання ІКТ у середній освіті. Прийняття важливих рішень щодо удосконалення шкільної освіти, зокрема шляхом упровадження в навчальний процес тих чи інших інформаційно-комунікаційних технологій, базується на вивченні відповідного досвіду та результатів відповідних досліджень. Велика кількість різноспрямованих наукових праць, які складають теоретико-практичну та методологічну базу використання ІКТ у шкільній освіті, зумовлює необхідність узагальнення, упорядкування й визначення їх типологічних ознак.

Автор теоретично обгрунтував умовне виокремлення таких груп досліджень, пов'язаних із використанням ІКТ у школі, як-от: узагальнювальні теоретико-аналітичні (документальні), емпіричні та комплексні. Кожна 3 груп досліджень характеризується варіативною сукупністю типологічних ознак за масштабністю та самостійністю їх проведення, що дає змогу виокремити основні їх типи (у статті розглянуто 10 типів досліджень, серед яких, наприклад, емпіричні/міжнародні широкомасштабні/контекстні дослідження або комплексні/локальні/самостійні дослідження тощо). Автор визначив структурнометодологічні критерії аналізу різних типів досліджень (тематичний, цільовий, вибірковий, організаційний, методичний, аналітичний, результативний) та здійснив вибірковий аналіз досліджень за запропонованими типологічними ознаками та структурно-методологічними критеріями, результати якого систематизовано в матриці методологічного аналізу різних типів досліджень щодо використання ІКТ у шкільній освіті.

За результатами огляду праць визначено актуальні тематичні напрями аналізованих досліджень, виявлено типові методи збору й аналізу відомостей та формат висвітлення результатів для кожної виокремленої групи досліджень.

Підхід до систематизації досліджень щодо використання ІКТ у закладах середньої освіти, представлений у пропонованій статті, може бути застосований під час оглядів наукових здобутків, аналізу педагогічних досліджень у галузі ІКТ або ж для проєктування власних досліджень. Заповнення запропонованої матриці аналізу дасть змогу використовувати іiі в подальшому як базу даних відповідних досліджень, полегшить пошук і відбір тих із них, які відповідають завданням конкретного наукового пошуку.
\end{abstract}

Ключові слова: ІКТ в освіті; методологія досліджень; типи досліджень; критерії методологічного аналізу. 


\title{
СТРУКТУРНО-МЕТОДОЛОГИЧЕСКИЕ АСПЕКТЫ ТИПОЛОГИЗАЦИИ ИССЛЕДОВАНИЙ ПО ИСПОЛЬЗОВАНИЮ ИКТ В ШКОЛЬНОМ ОБРАЗОВАНИИ
}

\author{
Гривко Антонина Викторовна \\ кандидат педагогических наук, \\ старший научный сотрудник отделамониторинга и оценивания качестваобщего среднего образования \\ Институт педагогики НАПН Украины, г. Киев, Украина \\ ORCID ID 0000-0001-9460-4777 \\ av.hryvko@gmail.com
}

Аннотация. В статье в методологическом аспекте рассмотрены вопросы систематизации исследований по использованию ИКТ в среднем образовании. Принятие важных решений по совершенствованию школьного образования, в том числе путем внедрения в учебный процесс тех или иных информационно-коммуникационных технологий, базируется на изучении соответствующего опыта и результатов соответствующих исследований. Большое количество разнонаправленных научных трудов, которые составляют теоретикопрактическую и методологическую базу использования ИКТ в школьном образовании, вызывает необходимость обобщения, упорядочения и определения их типологических признаков.

Автор теоретически обосновал условное выделение таких групп исследований, связанных с использованием ИКТ в школе, как: обобщающие теоретико-аналитические (документальные), эмпирические и комплексные. Каждая из групп исследований характеризуется вариативной совокупностью типологических признаков по масштабности и самостоятельности их проведения, что позволяет выделить основные их типы (в статье рассмотрено 10 типов исследований, среди которых, например, эмпирические/международные широкомасштабные/контекстные исследования или комплексные/локальные/самостоятельные исследования и т.п.). Автор определил структурно-методологические критерии анализа различных типов исследований (тематический, целевой, выборочный, организационный, методический, аналитический, результативный) и совершил выборочный анализ исследований по предложенным типологическим признакам и структурно-методологическими критериям, результаты которого систематизированы в матрице методологического анализа различных типов исследований по использованию ИКТ в школьном образовании.

По результатам осмотра работ определены актуальные тематические направления анализируемых исследований, выявлены типичные методы сбора и анализа сведений и формат освещения результатов для каждой выделенной группы исследований.

Подход к систематизации исследований по использованию ИКТ в учреждениях среднего образования, представленный в данной статье, может быть применен во время просмотра, анализа научных достижений, педагогических исследований в области ИКТ или для проектирования собственных исследований. Заполнение предложенной матрицы анализа позволит использовать ее в дальнейшем в качестве базы данных соответствующих исследований, облегчит поиск и отбор тех из них, которые отвечают задачам конкретного научного поиска.

Ключевые слова: ИКТ в образовании; методология исследований; типы исследований; критерии методологического анализа. 
APPENDIX A

\section{Matrix of methodological analysis of different research types on the use of ICT in secondary school education}

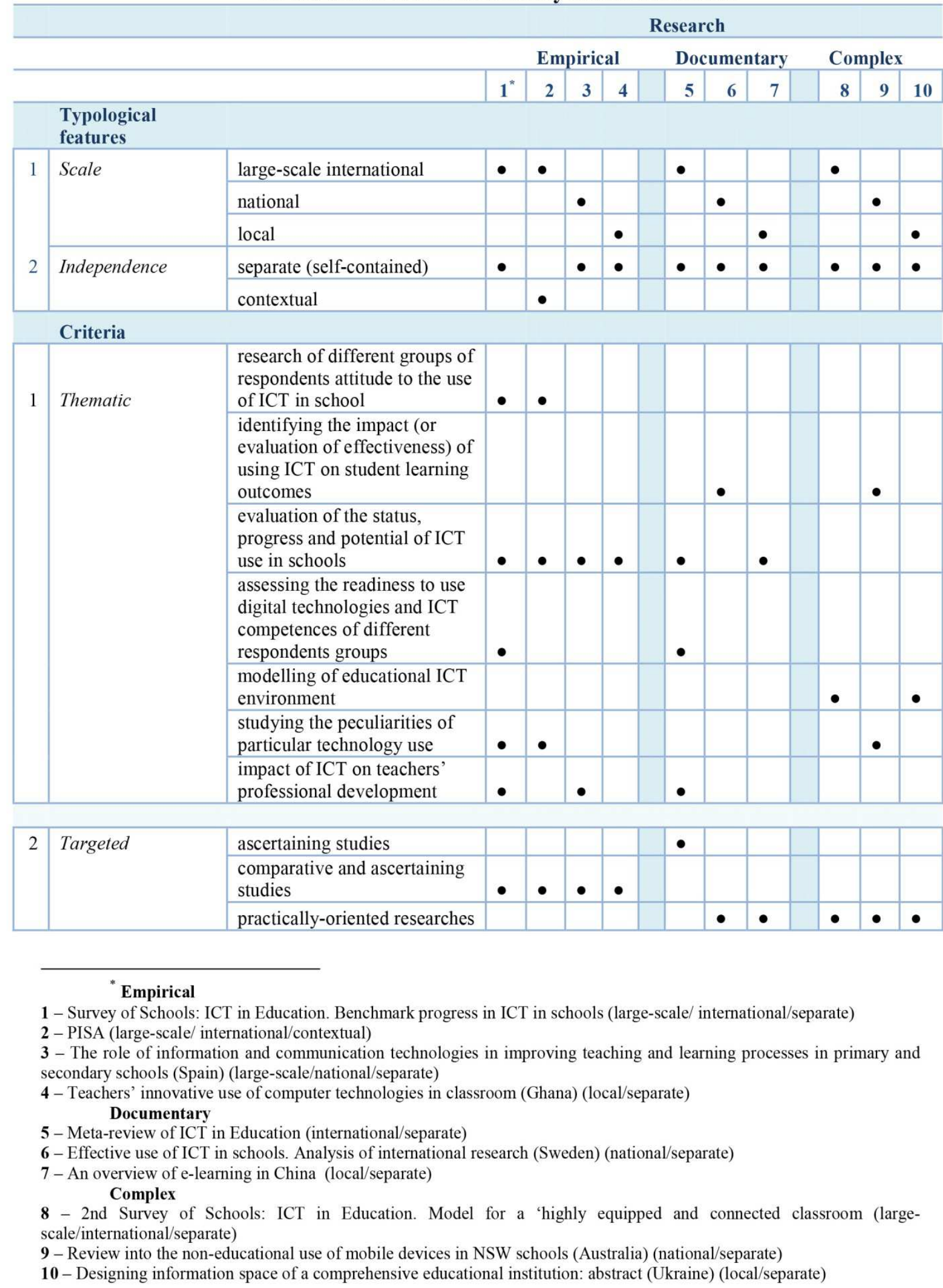


Continuation of Table

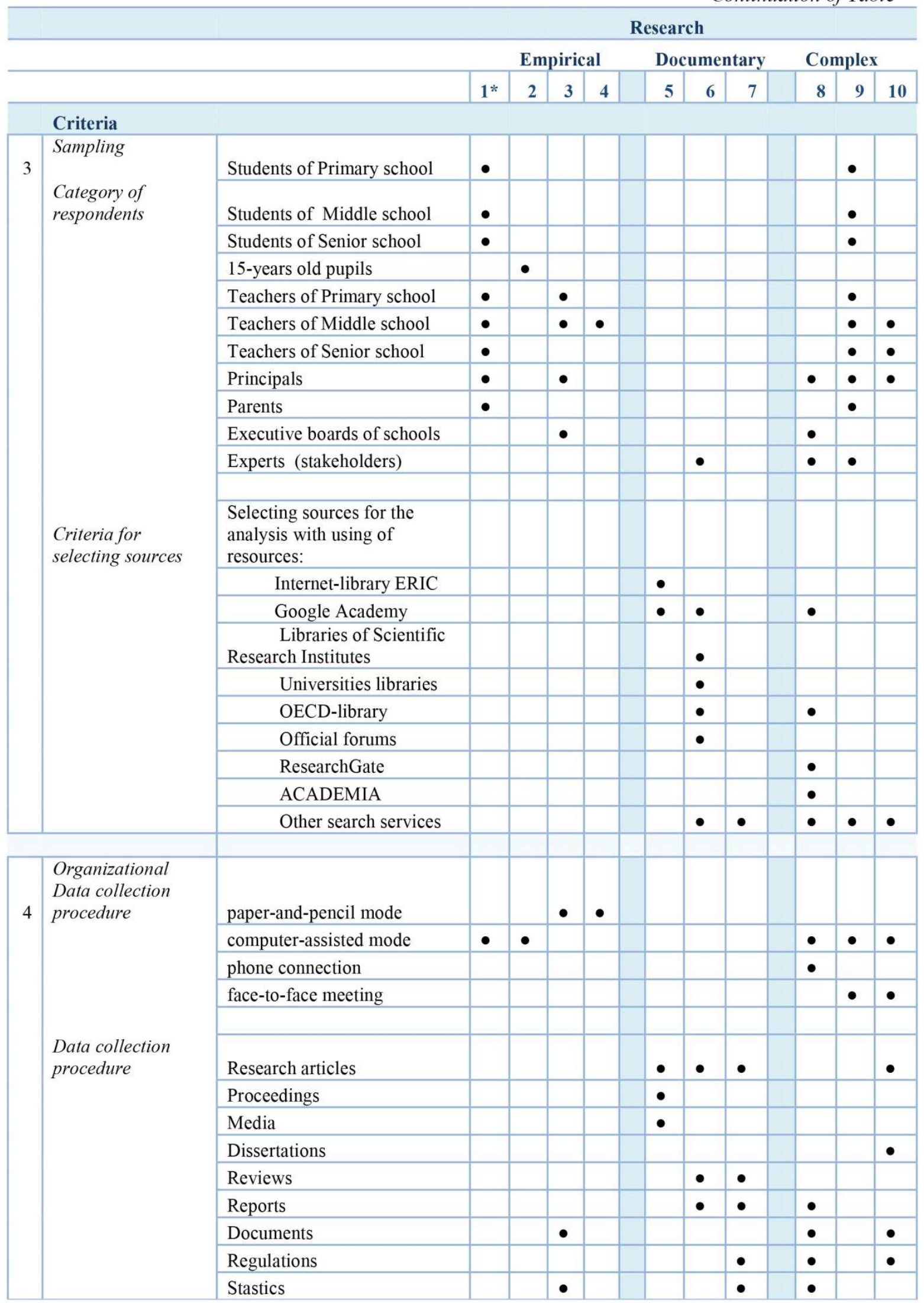


Continuation of Table

\begin{tabular}{|c|c|c|c|c|c|c|c|c|c|c|c|c|}
\hline & & & \multicolumn{10}{|c|}{ Research } \\
\hline & & & \multicolumn{4}{|c|}{ Empirical } & \multicolumn{3}{|c|}{ Documentary } & \multicolumn{3}{|c|}{ Complex } \\
\hline & & & $1^{*}$ & 2 & 3 & 4 & 5 & 6 & 7 & 8 & 9 & 10 \\
\hline \multicolumn{13}{|c|}{ Criteria } \\
\hline 5 & \multirow{10}{*}{$\begin{array}{l}\text { Methodological } \\
\text { Collection methods }\end{array}$} & surveys & $\bullet$ & $\bullet$ & $\bullet$ & $\bullet$ & & & & & $\bullet$ & $\bullet$ \\
\hline & & testing & & & & & & & & & & \\
\hline & & observation & & & & & & & & & & $\bullet$ \\
\hline & & interviews & & & & & & & & $\bullet$ & $\bullet$ & \\
\hline & & focus groups & & & & & & & & $\bullet$ & $\bullet$ & \\
\hline & & advices & & & & & & & & $\bullet$ & $\bullet$ & \\
\hline & & expert evaluation & & & & & & & & $\bullet$ & & $\bullet$ \\
\hline & & $\begin{array}{l}\text { analysis of the Internet market } \\
\text { goods and services }\end{array}$ & & & & & & & & $\bullet$ & & \\
\hline & & experiment & & & & & & & & & & \\
\hline & & literature analysis on the topic & & & & & $\bullet$ & $\bullet$ & $\bullet$ & $\bullet$ & $\bullet$ & \\
\hline & \multirow[t]{3}{*}{ Data type } & numeric & & & $\bullet$ & $\bullet$ & & & $\bullet$ & $\bullet$ & $\bullet$ & \\
\hline & & verbal & & & $\bullet$ & $\bullet$ & $\bullet$ & $\bullet$ & $\bullet$ & $\bullet$ & $\bullet$ & \\
\hline & & verbal-numerical & $\bullet$ & $\bullet$ & & & & & & & & \\
\hline & & & & & & & & & & & & \\
\hline \multirow[t]{10}{*}{6} & \multirow[t]{10}{*}{ Analytical } & $\begin{array}{l}\text { Methods of descriptive } \\
\text { statistic (mean, median, } \\
\text { mode) }\end{array}$ & $\bullet$ & $\bullet$ & $\bullet$ & $\bullet$ & & & & $\bullet$ & $\bullet$ & $\bullet$ \\
\hline & & Cronbach alpha's value & $\bullet$ & & & $\bullet$ & & & & & $\bullet$ & \\
\hline & & Univariate ANOVAs & $\bullet$ & & & & & & & $\bullet$ & & \\
\hline & & MANOVAs t-test & $\bullet$ & & & $\bullet$ & & & & & & \\
\hline & & Multiple Regression Analysis & $\bullet$ & & & $\bullet$ & & & & & & \\
\hline & & Cohen's d effect size & $\bullet$ & & & & & & & & & \\
\hline & & Cluster analysis method & $\bullet$ & $\bullet$ & & & & & & $\bullet$ & $\bullet$ & \\
\hline & & Correlative analysis & $\bullet$ & & $\bullet$ & & & & & & $\bullet$ & $\bullet$ \\
\hline & & Content-analysis & & & & & $\bullet$ & $\bullet$ & $\bullet$ & $\bullet$ & & $\bullet$ \\
\hline & & $\begin{array}{l}\text { Meta-analysis of open-ended } \\
\text { questions }\end{array}$ & & & & & & & & & $\bullet$ & \\
\hline & & & & & & & & & & & & \\
\hline \multirow[t]{10}{*}{7} & \multirow[t]{10}{*}{ Resultant } & Research article & $\bullet$ & $\bullet$ & $\bullet$ & $\bullet$ & & & $\bullet$ & & $\bullet$ & $\bullet$ \\
\hline & & Dissertation & & & & & & & & & & $\bullet$ \\
\hline & & Review & & & & & & & & & & \\
\hline & & Published observation & & & & & & & & & & \\
\hline & & Main report & $\bullet$ & & & & $\bullet$ & & & $\bullet$ & $\bullet$ & \\
\hline & & Technical report & $\bullet$ & & & & & & & & & \\
\hline & & Context report & & $\bullet$ & & & & & & & & \\
\hline & & Extended report & & & & & & $\bullet$ & & & & \\
\hline & & Guideline & & & & & & $\bullet$ & & & $\bullet$ & \\
\hline & & Manual & & & & & & & & & & $\bullet$ \\
\hline
\end{tabular}

\section{(cc) EY-NC-SA}

This work is licensed under Creative Commons Attribution-NonCommercial-ShareAlike 4.0 International License. 